University of Nebraska - Lincoln

DigitalCommons@University of Nebraska - Lincoln

USDA National Wildlife Research Center - Staff Publications
U.S. Department of Agriculture: Animal and Plant Health Inspection Service

2009

\title{
Field test of a single-injection gonadotrophin-releasing hormone immunocontraceptive vaccine in female white-tailed deer
}

James P. Gionfriddo

USDA-APHIS-Wildlife Services

John D. Eisemann

USDA/APHIS/WS National Wildlife Research Center, John.D.Eisemann@aphis.usda.gov

Kevin J. Sullivan

USDA-APHIS-Wildlife Services

Ronald S. Healey

USDA-APHIS-Wildlife Services

Lowell A. Miller

USDA-APHIS-Wildlife Services

See next page for additional authors

Follow this and additional works at: https://digitalcommons.unl.edu/icwdm_usdanwrc

Part of the Environmental Sciences Commons

Gionfriddo, James P.; Eisemann, John D.; Sullivan, Kevin J.; Healey, Ronald S.; Miller, Lowell A.; Fagerstone, Kathleen A.; Engeman, Richard M.; and Yoder, Christi A., "Field test of a single-injection gonadotrophinreleasing hormone immunocontraceptive vaccine in female white-tailed deer" (2009). USDA National Wildlife Research Center - Staff Publications. 915.

https://digitalcommons.unl.edu/icwdm_usdanwrc/915

This Article is brought to you for free and open access by the U.S. Department of Agriculture: Animal and Plant Health Inspection Service at DigitalCommons@University of Nebraska - Lincoln. It has been accepted for inclusion in USDA National Wildlife Research Center - Staff Publications by an authorized administrator of DigitalCommons@University of Nebraska - Lincoln. 


\section{Authors}

James P. Gionfriddo, John D. Eisemann, Kevin J. Sullivan, Ronald S. Healey, Lowell A. Miller, Kathleen A. Fagerstone, Richard M. Engeman, and Christi A. Yoder 


\title{
Field test of a single-injection gonadotrophin-releasing hormone immunocontraceptive vaccine in female white-tailed deer
}

\author{
James P. Gionfriddo ${ }^{\mathrm{A}, \mathrm{C}}$, John D. Eisemann ${ }^{\mathrm{A}}$, Kevin J. Sullivan ${ }^{\mathrm{B}}$, Ronald S. Healey ${ }^{\mathrm{B}}$, \\ Lowell A. Miller ${ }^{\mathrm{A}}$, Kathleen A. Fagerstone ${ }^{\mathrm{A}}$, Richard M. Engeman ${ }^{\mathrm{A}}$ and Christi A. Yoder ${ }^{\mathrm{A}}$ \\ A USDA/APHIS/Wildlife Services, National Wildlife Research Center, 4101 LaPorte Avenue, \\ Fort Collins, CO 80521, USA. \\ ${ }^{B}$ USDA/APHIS/Wildlife Services, 1568 Whitehall Road, Annapolis, MD 21401, USA. \\ ${ }^{\mathrm{C}}$ Corresponding author. Email: james.p.gionfriddo@aphis.usda.gov
}

\begin{abstract}
The development and use of safe, effective and practical wildlife contraceptive agents could reduce reproduction in locally overabundant deer populations in situations where traditional management tools such as regulated hunting cannot be employed. GonaCon Immunocontraceptive Vaccine (the commercial name for a particular gonadotrophin-releasing hormone (GnRH)-based emulsion) was tested in adult female white-tailed deer in a fenced herd near Silver Spring, Maryland, USA. Observations of udder condition were used to identify does that had become pregnant. Necropsy observations, histopathology and serum concentrations of anti-GnRH antibodies, luteinising hormone and progesterone were used to compare health and reproductive status of treated $(n=28)$ and control $(n=15)$ deer. After receiving one injection of GonaCon, $88 \%$ of treated deer did not become pregnant during the first year and $47 \%$ did not become pregnant during the second year after vaccination. No adverse health effects related to vaccination with GonaCon were detected, except for localised injectionsite reactions in five (29\%) of 17 examined, vaccinated deer. Treatment with GonaCon can be a safe and effective means of inducing temporary infertility in wild white-tailed deer. Ultimately, the management value of GonaCon will be determined by natural-resource professionals who use it as one of many tools to manage deer populations.
\end{abstract}

\section{Introduction}

Overabundant populations of native vertebrate species representing many taxa and trophic levels are causing adverse impacts on ecosystems throughout the world. They may degrade habitats and influence the distribution and abundance of sympatric floral and faunal populations (Martin 1985; Horsley et al. 2003). Natural diversity may be reduced as overabundant populations heavily exploit limited resources (St John 1997), displace competitors (Flowerdew and Ellwood 2001), spread infectious diseases and parasites (Gortázar et al. 2006), prevent forest regeneration (Palmer et al. 2004) and reduce the suitability of habitats for other species (Fuller and Gill 2001). Problems caused by overabundant wildlife populations have prompted the need for management solutions that address ecological, cultural and sociopolitical concerns. Efforts by natural-resource specialists to deal with overabundant wildlife have produced a growing body of literature, including several books (e.g. McShea et al. 1997b; Lunney et al. 2007) and special issues of scientific journals (e.g. Wildlife Society Bulletin 25(2), Wildlife Research 35(6)) devoted to the subject.

In many regions of the United States, white-tailed deer (Odocoileus virginianus) populations are locally overabundant (Daigle and Crête 1999). Major problems associated with overabundant deer are the increased frequency of collisions between deer and motor vehicles, and the human fatalities, injuries and property damage associated with such collisions (Etter et al. 2000). Other problems include extensive damage to native and ornamental vegetation (Rooney and Waller 2003) and adverse effects on forest community composition (Côté et al. 2004). Through their effects on forest understorey vegetation, overabundant deer can reduce avian biomass and diversity (McShea and Rappole 2000).

Management of overabundant deer in parks and in urban and suburban environments generally is undertaken to resolve conflicts between deer and human interests by reducing deer density. Although regulated hunting remains the most effective and efficient means of controlling deer, overabundant deer now inhabit many settings where hunting and the discharge of firearms are prohibited because of safety issues (e.g. Kuser and Applegate 1985). In addition, urban and suburban residents often prefer nonlethal wildlife-control methods such as contraception rather than lethal methods (Stout et al. 1997).

Although only one contraceptive agent is currently registered for use in wildlife in the United States (OvoControl for resident Canada geese (Branta canadensis) and pigeons (Columba livia); Innolytics LLC, Rancho Santa Fe, CA), a great deal of research effort has focussed on the development and testing of suitable wildlife contraceptives (Fagerstone et al. 2002). One of the more promising lines of research has led to the development of immunocontraceptive vaccines, which cause infertility by 
eliciting immune responses that block or otherwise disrupt normal reproductive processes. Several vaccines are being investigated for their effectiveness in controlling reproduction in ungulates (Patton et al. 2007). GonaCon immunocontraceptive vaccine (the commercial name for a particular gonadotrophinreleasing hormone (GnRH)-based emulsion; National Wildlife Research Center, Fort Collins, CO) has induced contraception in many mammalian species, including free-ranging California ground squirrels (Spermophilus beecheyi) (Nash et al. 2004), captive Norway rats (Rattus norvegicus) (Miller et al. 1997), domestic cats (Felis catus) (Levy et al. 2004), domestic and feral swine (Sus scrofa) (Killian et al. 2006c; Miller et al. 2003), wild horses (Equus caballus) (Killian et al. 2006a), bison (Bison bison) (Miller et al. 2004a) and white-tailed deer (Miller et al. 2008). GonaCon can be administered as a single injection that suppresses reproduction in treated animals of both sexes for multiple years (Miller et al. 2004b).

Our objective was to assess the efficacy and safety of GonaCon immunocontraceptive vaccine in wild white-tailed deer. We evaluated GonaCon's ability to suppress reproduction in adult female white-tailed deer by comparing pregnancy rates (as indicated by lactation during the fawning season) between GonaCon-treated does and unvaccinated, control does during a 2-year period. For each year, we tested the hypothesis that pregnancy rates did not differ between GonaCon-treated and untreated control deer. All aspects of this research were approved by the Institutional Animal Care and Use Committee of the National Wildlife Research Center (QA-1112).

\section{Materials and methods}

\section{Study area}

We field-tested GonaCon on two adjoining areas of land near Silver Spring in Montgomery and Prince George's counties, Maryland, USA (Fig. 1). Our research design was recommended by the US Food and Drug Administration's (FDA's) Center for Veterinary Medicine (CVM), which had jurisdiction over wildlife contraceptives when the present study began. Although no pretreatment data were available, the two areas were matched for their proximity and apparent ecological similarity to ensure that vaccination with GonaCon would be the likely explanation for observed differences in reproduction between treated and control deer. One site, which was called the Federal Research Center at White Oak (White Oak), was a mostly forested, fully fenced, 268-ha (662-acre) property managed by the US General Services Administration. An estimated 50-80 deer inhabited White Oak in November 2003, after 214 deer were removed by sharpshooters (K. J. Sullivan, USDA APHIS, pers. obs.).

The study area also included an 82-ha (202-acre) US Department of Defence property known as the US Army Adelphi Laboratory Center (Adelphi), which abutted about half of the southern and eastern edges of White Oak (Fig. 1). Except along this common boundary, most of the land bordering White Oak and Adelphi consisted of suburban residential development. The Adelphi site also was fully fenced and its vegetation, topography and availability of lawns and landscaped areas were very similar to those at White Oak. No hunting occurred on either site. An estimated 50 deer inhabited

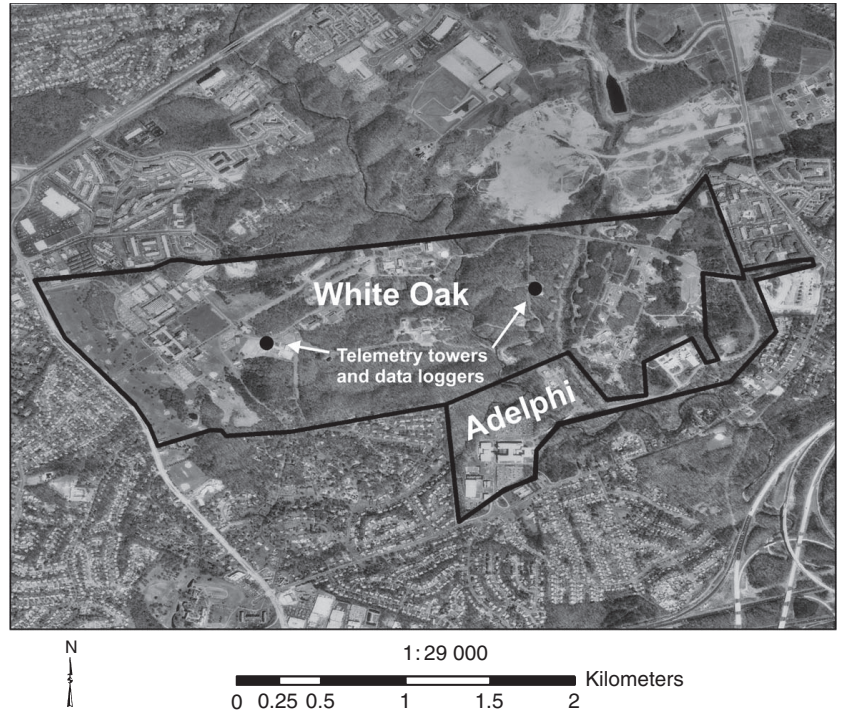

Fig. 1. Field study sites at the Federal Research Center at White Oak and the Adelphi Army Laboratory Center, Silver Spring, Maryland, USA, 2004-2006.

Adelphi in November 2003 (K. J. Sullivan, USDA APHIS, pers. obs.). Does at Adelphi were used as untreated control animals in our field study. Initially, GonaCon-treated and control deer were segregated spatially in the present study, at the recommendation of the CVM and in compliance with US Environmental Protection Agency (EPA) guidelines (Schneider 1982) for field testing of vertebrate-control products for registration purposes. Spatial segregation was compromised throughout the study, however, by occasional storm-induced damage to interior and perimeter fences. Although fences were repeatedly repaired, at least 10 study deer moved between White Oak and Adelphi, and at least five study deer moved on and off the study area during the 2-year field study.

\section{Capture and treatments}

The GonaCon immunocontraceptive vaccine formulation consisted of mammalian GnRH conjugated to a large mollusk hemocyanin protein (keyhole limpet hemocyanin (KLH)) and emulsified in AdjuVac adjuvant. Each 1.0-mL dose contained $1000 \mu \mathrm{g}$ of the conjugate. GonaCon was stored and shipped under refrigerated conditions in pre-loaded, 3-mL Air-Tite (Air-Tite Products, Virginia Beach, VA) luer-hub syringes.

During July and August 2004, we immobilised and captured adult female deer with tranquiliser darts that contained a mixture of $4.5 \mathrm{mg} \mathrm{kg}^{-1}$ Telazol (Fort Dodge Animal Health, Fort Dodge, IA) and $2.5 \mathrm{mg} \mathrm{kg}^{-1}$ Xylazine (Bayer, Leverkusen, North Rhine-Westphalia, Germany). Dosage was based on estimated body mass of deer. Each captured doe was examined physically for signs of injury, illness or malnutrition. Deer that were injured, sick or malnourished were not included in the study. We fitted each study doe with two types of ear tags (coloured, numbered, plastic livestock tags, and numbered aluminum tags). Aluminum ear tags bore the message, 'Experimental animal, do not consume deer' plus a contact 
telephone number. To permit prompt recovery of carcasses in the event of mortality of study animals, deer were also fitted with radio-telemetry collars equipped with mortality sensors (Model M2520, Advanced Telemetry Systems, Isanti, MN) that allowed monitoring via an automated, fixed-station radio-telemetry system. We monitored respiration and heart rates as deer were processed. We gave an intravenous injection of $3.0 \mathrm{mg} \mathrm{kg}^{-1}$ Tolazine (Lloyd Inc., Shenandoah, IA) to each doe to reverse anaesthesia and hasten recovery. At White Oak, each captured doe was injected (IM in the upper rear leg) with $1 \mathrm{~mL}$ of GonaCon vaccine. We used a $3-\mathrm{mL}$ syringe equipped with a $1-1 / 2-i n c h$, 19-gauge hypodermic needle for each GonaCon injection. At Adelphi, we captured, marked and released does as unvaccinated control animals. Control deer were not injected in the present study because an earlier study of captive white-tailed deer had detected no effects of sham injection of control animals (Killian et al. 2006b).

\section{Evaluation of contraceptive efficacy}

The reproductive status of each marked doe was assessed during the summers of 2005 and 2006 by visual inspection of udders for signs of lactation as an indicator of current or recent pregnancy (Pojar and Bowden 2004). The inspection of mammary glands for recent activity is a convenient, noninvasive method of monitoring reproductive activity in many mammalian populations (Harder and Kirkpatrick 1994). Cervid reproductive status often has been assessed by documenting lactation rates of hunter-killed, road-killed, or researchercollected animals through palpation of udders (Rhodes et al. 1986) or through field observations of udder condition (Pojar and Bowden 2004). A prominent udder indicates that a female cervid will soon give birth or has already given birth (Whitten 1995). A limitation of this method is its inability to detect embryonic or early neonatal losses (and the resultant termination of lactation), which could result in an overestimation of contraceptive efficacy. However, our intensive summer field observations of experimental does were begun before the onset of the fawning season each year, to enable us to detect pregnancies that were followed by late prenatal or early neonatal mortality. Most observations were made from $<50 \mathrm{~m}$ with binoculars or a spotting telescope, and most females were evaluated by multiple field observers whose conclusions were highly consistent. For example, in all 17 cases in which a doe's reproductive status was evaluated within a single breeding season by three to five different observers, the assessments agreed. Moreover, in 17 of 18 other cases in which a doe's condition was evaluated by two observers, the results agreed. Of 30 instances in which an unequivocal evaluation of the udder condition of an experimental doe was made by only one observer during a given breeding season, numerous additional (but slightly less certain) observations made by that observer or by other observers during that breeding season supported the unequivocal observation in 29 cases. (In the remaining case, there were no additional observations.)

We used Fisher's exact tests to compare, for each year, the proportion of GonaCon-treated does that lactated with the proportion of untreated does that lactated. The experimental unit was the individual study deer.
Evaluation of serum concentrations of anti-GnRH antibodies, luteinising hormone and progesterone

To evaluate the immune responses of deer to vaccination with GonaCon, we used enzyme-linked immunosorbent assay (ELISA) to measure serum anti-GnRH titers (Muller et al. 1997) and radioimmunoassay (RIA) to measure serum concentrations of luteinising hormone (LH) and progesterone (Plotka et al. 1980) in blood collected from vaccinated and control deer at the end of field operations in October-November 2006, $\sim 27$ months after injections were given.

\section{Evaluation of health effects of vaccination on treated deer}

To identify potential health and safety issues related to the use of GonaCon in white-tailed deer, we used postmortem observations and histopathological analyses of reproductive and other tissues to assess the condition of experimental deer that died during the study or were collected at the end of the study. We collected deer after shooting them in the head or neck with a high-powered rifle, and we sampled blood via cardiac puncture immediately after the deer died. Blood samples were stored in a cooler or a refrigerator until they were centrifuged, and then the serum was shipped to a laboratory for analysis. We took deer carcasses to a Maryland Department of Agriculture Animal Health Diagnostic Laboratory for necropsy by a veterinary pathologist. Samples of specified tissues were collected during necropsy, fixed and preserved in formalin, and shipped to NWRC headquarters in Fort Collins, Colorado, for storage until histopathological analyses were performed by a local laboratory (Colorado Histo-Prep, Fort Collins, CO). Tissues collected during necropsy included both ovaries, both fallopian tubes, the uterus, hypothalamus/pituitary gland, mammary gland and the GonaCon injection site plus its draining (popliteal and iliac) lymph nodes. In addition, any other apparently abnormal tissues were collected for histopathological evaluation.

\section{Results}

\section{Contraceptive efficacy}

During July and August 2004, we captured, marked, vaccinated and released 28 does at White Oak, and we captured, marked and released 15 control does at Adelphi (Table 1). Two GonaContreated does died from unknown causes during the breeding season in November and December 2004. A third GonaContreated doe (G22) was struck and killed by a car during April 2005 (during the third trimester of most local white-tailed deer pregnancies); she was not pregnant at the time and because her reproductive status was determined, she was included in the 2005 sample (Table 1).

During field observations of udder condition in spring and summer 2005, we documented the reproductive status of 13 of the 15 control does at Adelphi (udders of two does were not observed closely enough to draw firm conclusions regarding lactation). In all, 11 (85\%) of those 13 does lactated during 2005. At White Oak, we obtained unequivocal observations for 26 of the 28 does that had been injected with GonaCon vaccine. Lactation was evident in only $3(12 \%)$ of these 26 treated does (including road-killed doe G22 - see above) 
Table 1. Reproductive status of GonaCon-treated and control white-tailed deer females in Maryland, USA, 2005-2006

\begin{tabular}{lccccccc}
\hline $\begin{array}{l}\text { Treatment } \\
\text { group }\end{array}$ & $n(2004)$ & $n(2005)$ & $\begin{array}{c}\text { Pregnant } \\
(2005)\end{array}$ & $\begin{array}{c}\text { Not pregnant } \\
(2005)\end{array}$ & $n(2006)$ & $\begin{array}{c}\text { Pregnant } \\
(2006)\end{array}$ & $\begin{array}{c}\text { Not pregnant } \\
(2006)\end{array}$ \\
\hline GonaCon & 28 & 26 & $3(12 \%)^{\mathrm{A}}$ & $23(88 \%)$ & 19 & $10(53 \%)^{\mathrm{B}}$ & $9(47 \%)$ \\
Control & 15 & 13 & $11(85 \%)^{\mathrm{A}}$ & $2(15 \%)$ & 10 & $10(100 \%)^{\mathrm{B}}$ & $0(0 \%)$ \\
\hline
\end{tabular}

${ }^{\mathrm{A}}$ Rates of pregnancy differed between GonaCon-treated and control deer during 2005 (Fisher's exact test, $P \leq 0.0001$ ).

${ }^{\mathrm{B}}$ Rates of pregnancy differed between GonaCon-treated and control deer during 2006 (Fisher's exact test, $P=0.0114$ ).

(Table 1). Rates of pregnancy differed between GonaCon-treated and control deer (Fisher's exact test, $P \leq 0.0001$ ).

During spring and summer 2006 , we determined the reproductive status of 10 control and 19 vaccinated does through observations of udder condition (Table 1). Four control does and six treated does had died during the previous year because of predation $(n=7)$ or collisions with motor vehicles $(n=3)$. Reproductive status could not be determined for the deer killed by predators or for one of the vehicle-killed deer, whereas the other two vehicle-killed deer (one vaccinated and one control doe) were pregnant at necropsy. Among the study animals for which reproductive status was known, all $10(100 \%)$ of the control does, and $10(53 \%)$ of 19 GonaCon-treated does had become pregnant during the second year of the study (Table 1). Rates of pregnancy during
2006 differed between GonaCon-treated and control deer (Fisher's exact test, $P=0.0114$ ).

\section{Serum concentrations of anti-GnRH antibodies, luteinising hormone and progesterone}

At the end of the field study, serum anti-GnRH antibody titers were measured in 19 ( 11 treated and 8 control) deer. No antibodies to GnRH were detected in control deer, whereas titers ranged from $1: 2$ to $1: 128000$ in vaccinated deer. High titers were associated with a contraceptive effect (Table 2).

Serum concentrations of LH and progesterone in the 19 deer collected at the end of the study were within normal ranges (Plotka et al. 1977; Harder and Moorhead 1980) and generally were unremarkable (Table 2). An LH value of $7.44 \mathrm{ng} \mathrm{mL}^{-1}$ in one

Table 2. Reproductive organ condition, blood serum anti-GnRH antibody titers and serum concentrations of luteinising hormone and progesterone of adult, female, white-tailed deer in GonaCon-treated (G) and control (C) groups at the Federal Research Center at White Oak and the Adelphi Army Laboratory Center in Silver Spring, Maryland, USA, October-November 2006

Reproductive status for 2005 and 2006 also is given for each deer. NS, no sample; ND, not detectable

\begin{tabular}{|c|c|c|c|c|c|c|c|c|}
\hline $\begin{array}{l}\text { Deer } \\
\text { number }\end{array}$ & $\begin{array}{c}\text { Udder } \\
\text { condition }^{\mathrm{A}} \\
\text { (June 2006) }\end{array}$ & $\begin{array}{c}\text { Mammary } \\
\text { glands }^{B}\end{array}$ & Uterus $^{\mathrm{C}}$ & $\begin{array}{c}\text { Anti-GnRH } \\
\text { antibody titer } \\
\left.\text { (titer }^{-1} \times 1000\right) \\
(2006)\end{array}$ & $\begin{array}{c}\text { Luteinising } \\
\text { hormone } \\
\left(\mathrm{ng} \mathrm{mL}^{-1}\right) \\
(2006)\end{array}$ & $\begin{array}{l}\text { Progesterone } \\
\left(\mathrm{ng} \mathrm{mL}^{-1}\right) \\
(2006)\end{array}$ & $\begin{array}{c}\text { Pregnant? } \\
(2005)\end{array}$ & $\begin{array}{c}\text { Pregnant? } \\
(2006)\end{array}$ \\
\hline G6 & 1 & 3 & 5 & 4 & 0.51 & 0 & Yes & Yes \\
\hline$G 7^{\mathrm{D}}$ & 2 & 2 & 4 & 128 & 0.22 & 0 & No & Yes \\
\hline G8 & 3 & 3 & 5 & 128 & 0.22 & 0.2 & No & No \\
\hline G11 & 1 & 1 & 2 & 128 & 0.30 & NS & No & Yes \\
\hline G14 & 3 & 3 & 5 & 128 & 0.15 & 0 & No & No \\
\hline G20 & 2 & 1 & 5 & 2 & 0.51 & 0.1 & No & Yes \\
\hline $\mathrm{G} 21$ & 2 & 2 & 4 & 4 & 0.47 & 0 & No & Yes \\
\hline G23 & 2 & 1 & 5 & 4 & 0.54 & 0 & Unknown & Yes \\
\hline G25 & 1 & 1 & 4 & 4 & 0.19 & 0 & No & Yes \\
\hline G26 & 3 & 2 & 4 & 128 & 0.33 & 0.5 & No & No \\
\hline G28 & 1 & 1 & 3 & 8 & 0.62 & 0 & No & Yes \\
\hline $\mathrm{C} 1$ & 1 & 2 & 5 & ND & 0.22 & 4.2 & Yes & Yes \\
\hline $\mathrm{C} 2$ & 1 & 1 & 5 & ND & 0.39 & 0.2 & Yes & Yes \\
\hline $\mathrm{C} 5$ & 1 & 1 & 5 & ND & 0.47 & 0.1 & Yes & Yes \\
\hline C6 & 2 & 1 & 5 & ND & 0.33 & 0.1 & Yes & Yes \\
\hline C7 & 1 & 1 & 5 & ND & 0.38 & 0 & Yes & Yes \\
\hline C9 & 1 & 1 & 1 & ND & 1.15 & 0 & Yes & Yes \\
\hline $\mathrm{C} 11$ & 1 & 1 & 1 & ND & 7.44 & 0 & Yes & Yes \\
\hline $\mathrm{C} 12$ & 1 & 3 & 5 & ND & 0.45 & 0.1 & Yes & Yes \\
\hline
\end{tabular}

$\mathrm{A}_{1}=$ greatly distended; $2=$ moderately distended; $3=$ not distended.

${ }^{\mathrm{B}} 1=$ enlarged, with milk; $2=$ small, inactive; $3=$ no comment made at necropsy.

${ }^{\mathrm{C}}$ All uteri were non-gravid. 1 = large, flaccid; $2=$ moderately enlarged; $3=$ moderately distended, thin-walled horns; $4=$ small; $5=$ no comment made at necropsy.

${ }^{D}$ Deer G7 was mistakenly given a boost injection of GonaCon vaccine during late September 2006. That injection may have influenced the anti-GnRH antibody titer and the condition of mammary glands, ovaries, and uterus when the animal was collected 7 weeks later. 
control doe (C11) indicated that she was ovulating (Plotka et al. 1980) when killed (on 8 November 2006).

\section{Health effects of vaccination on treated deer}

At necropsy, 18 of the 19 deer collected at the end of the 2-year field study were qualitatively described by the veterinary pathologist as being in at least 'good to excellent' nutritional condition and as having at least 'adequate' body fat. One of the control does (C1), at $42 \mathrm{~kg}$, was in 'fair to poor' nutritional condition, with 'very scant' body fat.

No abnormalities were noted at necropsy among GonaContreated or control deer with respect to the condition of their brains, pituitary glands, ovaries, hearts, lungs, livers, kidneys, spleens, intestines, caudal oropharynxes, mesenteric lymph nodes, gastrohepatic lymph nodes, iliac lymph nodes or retropharyngeal lymph nodes. No abnormalities were found in mammary glands of necropsied deer, although size and condition of mammary glands varied with recent reproductive history (Table 2). Enlarged mammary glands that contained milk were noted in five GonaCon-treated deer and in six control deer, all of which had been classified as pregnant during 2006. Small, inactive mammary glands were found in three GonaCon-treated does and in the one control doe (C1) that was in 'fair to poor' nutritional condition. Uteri of all 19 deer collected at the end of the study in late October-early November 2006 were non-gravid. Four of the GonaCon-treated deer had relatively small uteri; three other deer (one treated and two control deer, all of whom had been pregnant during 2006) had large or moderately enlarged uteri (Table 2). Popliteal lymph nodes (which drain the upper rear legs) were slightly enlarged in two deer (one GonaCon-treated and one control), but histopathological analysis of the enlarged nodes detected no pathology.

Necropsies were performed on 7 (six GonaCon-treated and one control) of the 14 deer that died during the 2-year field study in addition to the 19 deer that were collected at the conclusion of field activities. At necropsy, vaccine injection sites were detected in $5(29 \%)$ of 17 GonaCon-treated deer, and collected for histopathological evaluation. At four of these five injection sites, intramuscular tissue reactions were discovered at necropsy via gross physical examination. In the necropsy reports, two of these reactions were characterised by the veterinary pathologist as chronic abscesses, and a third reaction was described as a soft, yellow-white, granulomatous nodule $\left(6 \mathrm{~cm}^{3}\right)$. The larger abscess $\left(150 \mathrm{~cm}^{3}\right)$ was characterised as moderately severe and chronic, and it contained markedly viscous, pale yellow-green purulent material. The smaller abscess $\left(3 \mathrm{~cm}^{3}\right)$, which was described as mild, localised and chronic, contained similar purulent material. The fourth injection-site reaction was described simply as a golf ballsized abscess $\left(\sim 40 \mathrm{~cm}^{3}\right)$.

Histopathological examination of the five injection-site tissue samples detected severe, local lesions of a granulomatous and necrotising myositis in all five cases. The lesions typically contained macrophages, lymphocytes and giant cells, and most were partially encapsulated with thick, fibrous connective tissue. No other injection-related lesions were detected in GonaContreated deer.

\section{Discussion}

\section{Contraceptive efficacy}

Near- $100 \%$ contraceptive efficacy may not be possible under field conditions (Rudolph et al. 2000). Earl et al. (2006) noted that the efficacy of laboratory trials of contraceptive vaccines sometimes was noticeably greater than that demonstrated in subsequent field studies. The results of earlier GonaCon trials with captive whitetailed deer at Pennsylvania State University (Miller et al. 2000, 2008) and those of the field study reported here followed this pattern. Among captive female deer $(n=8)$, contraceptive efficacy across all 4 years of the study was $83 \%$ (Miller et al. 2000). Four of 5 GonaCon-treated captive deer in another study at Penn State remained infertile for at least 5 years after vaccination (Miller et al. 2008). Although efficacy among treated free-ranging deer in the present field study in Maryland was $88 \%$ during the first reproductive season after vaccination, it declined to $47 \%$ during the second year. A similar field trial of GonaCon in female white-tailed deer was completed recently in New Jersey, where contraceptive efficacy rates $(n=24)$ were $67 \%$ (Year 1$)$ and $48 \%$ (Year 2) (J. P. Gionfriddo, unpubl. data). In a field study in New York in which white-tailed does $(n=32)$ were treated by remote injection with a prime and two boost doses of an early formulation of GnRH vaccine, Curtis et al. (2002) reported an $87 \%$ contraceptive efficacy rate among treated does for each of the first 2 years after initial vaccination. Efficacy (as measured by the proportion of treated females that became infertile) declined to $71 \%$ during the third year and to $43 \%$ during the fourth year after initial treatment (Curtis et al. 2002).

Vaccination with GonaCon was associated with substantially reduced reproduction of adult female white-tailed deer in our study. We did not demonstrate that reproductive success of vaccinated and untreated control deer would have been similar in the absence of vaccination, and therefore we have shown correspondence but not causation. The argument that GonaCon caused the observed differences in reproduction, however, is strongly supported by abundant efficacy data from previous GonaCon studies and by antibody and necropsy results from the present study (see below). Although vaccinated and control deer were initially segregated spatially, storm-caused damage to fences enabled deer to move freely between White Oak and Adelphi during the study. Pseudoreplication (sensu Hurlbert 1984) is not a problem in this longitudinal study because of the interspersion of study deer and the limited breadth of inferences that we draw from the results.

\section{Serum concentrations of anti-GnRH antibodies, luteinising hormone and progesterone}

The presence of circulating, neutralising antibodies is the most commonly used measure of response to vaccination (Purswell and Kolster 2006). GnRH serum antibody titers can be a good indicator of the probability of effective contraception in the treated individual (McShea et al. 1997a). Contraception is achieved only when a critical threshold level of immunological response is reached and maintained (Adams and Adams 1990; Zeng et al. 2002). In white-tailed deer, for example, anti-GnRH antibody titers $\geq 1: 64000$ generally are associated with infertility (Miller et al. 2000). Of the 11 GonaCon-treated does in which anti-GnRH titers were measured after Year 2 in our 
study, five had titers of $1: 128000$ (Table 2). The other six deer, which had titers of $1: 2$ to $1: 8$, had all been pregnant during 2006 . Anti-GnRH titers in vaccinated animals decrease over time (Miller et al. 2000, 2004a; Killian et al. 2006c); however, we do not know whether these six deer initially produced strong immune responses that later subsided, or whether they simply never responded. Variation among animals' responses to GnRH vaccines may be due to genetic variation within the tested groups (Cooper and Herbert 2001) or to variation in other factors such as health status or stress (de Groot et al. 1999; Burns et al. 2003).

Although the five GonaCon-treated deer with anti-GnRH titers of $1: 128000$ at recapture during October-November 2006 would be expected to be infertile, two of them had been pregnant during spring 2006. We have no explanation for one of these anomalies (G11). In the second case, however, the doe (G7) had been mistakenly recaptured during late September 2006 and given a boost injection of GonaCon. Evidently, the boost dose had elicited a strong immune response, causing the production of high levels $(1: 128000)$ of anti-GnRH antibody (and probably reducing the sizes and activity of mammary glands and uterus - see Table 2) by the time of her death by gunshot 7 weeks later.

\section{Health effects of vaccination on treated deer}

By using field observations, detailed necropsies and histopathological examination of reproductive and other vital organs and tissues, we did not detect any substantive differences between vaccinated and control animals, other than localised lesions at injection sites (present in 5 (29\%) of 17 vaccinated deer that were examined). Mammary glands, ovaries and uteri in several GonaCon-treated does were smaller than those in control deer; however, these differences were attributable to differences in recent reproductive history among individuals. In addition, GnRH vaccines typically cause a noticeable reduction in the size (Elhay et al. 2007) or growth (Zeng et al. 2002) of these structures. A previous evaluation of the health effects of GonaCon use in captive white-tailed deer also found no adverse effects on reproductive organs (Killian et al. 2006b).

In the five GonaCon-treated does that had experienced injection-site reactions in the hind leg musculature, no adverse reactions were evident during external examination because reactions had occurred internally at the intramuscular vaccine depot sites rather than at the injection-site skin surface. Four injection-site reactions were detected at necropsy by the veterinary pathologist, and the fifth was identified only during subsequent histopathological examination of tissue samples collected at necropsy. The necropsy pathologist stated that the largest $\left(150 \mathrm{~cm}^{3}\right)$ tissue reaction, a very well encapsulated granuloma, was not a source of systemic infection, was not presenting an ongoing challenge to the general health and well being of the deer and probably did not affect locomotion.

Adjuvants sometimes induce undesirable reactions, such as granulomas, at injection sites (Stills and Bailey 1991; Curtis et al. 2007). The presence of killed Mycobacterium avium in AdjuVac, the adjuvant used in the preparation of GonaCon, is probably responsible for the injection-site reactions observed in our study (Killian et al. 2006b). Similar reactions were common among
GonaCon-treated and sham-injected, control white-tailed deer in our New Jersey field study, whereas they did not occur among non-injected control deer (J. P. Gionfriddo, unpubl. data). The sham material given to some New Jersey control deer consisted of AdjuVac adjuvant and mollusk stabilising buffer, without the GnRH and mollusk carrier molecule. AdjuVac is a diluted form of Mycopar(Fort Dodge Animal Health, Fort Dodge, IA), which is a USDA-approved (USDA Veterinary Licence 112) Johne's vaccine for use in cattle. Used in young cattle to decrease infection with Mycobacterium avium paratuberculosis, Mycopar often causes injection-site granulomas (J. C. Rhyan, USDA APHIS, pers. comm.). AdjuVac contains less than $1 \%$ of the $M$. avium present in Mycopar, and it causes fewer and smaller granulomas (J. C. Rhyan, USDA APHIS, unpubl. obs.). The presence of $M$. avium is probably necessary for GonaCon to be effective as a single-shot formulation (Perry et al. 2008).

\section{Management implications}

The use of injectable contraceptives such as GonaCon may be best suited to sites that are enclosed, allow easy access to deer and are inhabited by deer that permit human approach for darting or trapping (DeNicola et al. 1996). Intensive, selective management of deer and other cervids on such sites may be possible with contraceptive agents, although this hypothesis remains to be tested. In general, the use of injectable contraceptives for deer may be limited by practical and legal constraints to small parks, corporate campuses, and urban and suburban settings (Rutberg et al. 2004). A full exploration and critique of GonaCon and other immunocontraceptive vaccine formulations, and associated experimental methods, is beyond the scope of this paper, but will be the subject of a future review by the authors.

Culling is more effective than contraception in reducing the size of a deer population to a desired level (Hobbs et al. 2000). In areas where hunting options are limited, successful management of overabundant deer populations would be best achieved through an initial reduction in population size to the desired level, followed by maintenance of that size via contraception or additional culling (Hobbs et al. 2000; Merrill et al. 2003). This approach is probably the most practical solution for reducing and stabilising a locally overpopulated deer herd.

GonaCon vaccine could become a useful addition to the tools used by wildlife professionals to reduce reproduction in overabundant wild animals in settings where other management methods such as regulated hunting cannot be applied. Demonstrating contraceptive efficacy in individual animals, as we have done in the present study, however, is very different from demonstrating population-level effects (Rutberg et al. 2004). The efficacy and practicality of contraception as a population-management tool have not yet been established (Hobbs et al. 2000). Among the factors that would influence the population-level response to immunocontraception are the proportion of females that can be treated, the incidence of non-responders among treated deer, the fertility of untreated animals, compensatory responses such as increased reproductive rates in untreated individuals and increased survival of treated individuals, as well as rates of mortality, immigration and emigration. Population-level responses to treatment with immunocontraceptives are likely 
to be situation-specific, and evaluation of such responses should proceed on a case-by-case basis once a contraceptive agent has been registered by the EPA and is in operational use. Ultimately, the value of GonaCon will be determined by natural-resource professionals who use it as one of many tools to manage deer populations.

\section{Acknowledgements}

This research was funded by the USDA Animal and Plant Health Inspection Service (APHIS) and the US General Services Administration. Scientists employed by the USDA APHIS were involved in the collection, analysis and interpretation of data, and in the writing of the manuscript. The US General Services Administration (GSA) and its employees had no such involvement in the study. We thank the GSA and the US Army Laboratory at Adelphi for providing a study site and for logistical assistance that was invaluable to the success of this study. We are very grateful to C. M. Bens, J. B. Bourassa, L. Clark, K. A. Crane, K. B. Cross, R. J. Dimayuga, Jr, D. C. Emanueli, R. H. Fey, B. B. German, T. C. Hall, S. Jojola, J. M. Kemp, G. J. Killian, T. C. Mathies, J. R. O'Hare, G. E. Phillips, V. J. Pierce, A. A. Reed, J. J. Smith, $\mathrm{R}$. Wardwell and three anonymous reviewers for help with various aspects of the study or with the preparation of this manuscript.

\section{References}

Adams, T. E., and Adams, B. M. (1990). Reproductive function and feedlot performance of beef heifers actively immunized against GnRH. Journal of Animal Science 68, 2793-2802.

Burns, V. E., Carroll, D., Ring, C., and Drayson, M. (2003). Antibody response to vaccination and psychosocial stress in humans: relationships and mechanisms. Vaccine 21, 2523-2534. doi: 10.1016/ S0264-410X(03)00041-0

Cooper, D. W., and Herbert, C. A. (2001). Genetics, biotechnology and population management of over-abundant mammalian wildlife in Australasia. Reproduction, Fertility and Development 13, 451-458. doi: 10.1071/RD01072

Côté, S. D., Rooney, T. P., Tremblay, J.-P., Dussault, C., and Waller, D. M. (2004). Ecological impacts of deer overabundance. Annual Review of Ecology Evolution and Systematics 35, 113-147. doi: 10.1146/ annurev.ecolsys.35.021103.105725

Curtis, P. D., Pooler, R. L., Richmond, M. E., Miller, L. A., Mattfeld, G. F., and Quimby, F. W. (2002). Comparative effects of GnRH and porcine zona pellucida (PZP) immunocontraceptive vaccines for controlling reproduction in white-tailed deer (Odocoileus virginianus). Reproduction (Cambridge, England) Supplement 60, 131-141.

Curtis, P. D., Richmond, M. E., Miller, L. A., and Quimby, F. W. (2007). Pathophysiology of white-tailed deer vaccinated with porcine zona pellucida immunocontraceptive. Vaccine 25, 4623-4630. doi: 10.1016/ j.vaccine.2007.03.033

Daigle, C., and Crête, M. (1999). Management of indigenous North American deer at the end of the 20th century in relation to large predators and primary productivity. Acta Veterinaria Hungarica 47, 1-16. doi: 10.1556/ AVet.47.1999.1.1

de Groot, J., van Milligen, F. J., Moonen-Leusen, B. W. M., Thomas, G., and Koolhaas, J. M. (1999). A single social defeat transiently suppresses the anti-viral immune response in mice. Journal of Neuroimmunology $\mathbf{9 5}$, 143-151. doi: 10.1016/S0165-5728(99)00005-3

DeNicola, A. J., Kesler, D. J., and Swihart, R. K. (1996). Ballistics of a biobullet delivery system. Wildlife Society Bulletin 24, 301-305.

Earl, E. R., Waterston, M. M., Aughey, E., Harvey, M. J. A., Matschke, C., Colston, A., and Ferro, V. A. (2006). Evaluation of two GnRH-I based vaccine formulations on the testes function of entire Suffolk cross ram lambs. Vaccine 24, 3172-3183. doi: 10.1016/j.vaccine.2006.01.041
Elhay, M., Newbold, A., Britton, A., Turley, P., Dowsett, K., and Walker, J. (2007). Suppression of behavioural and physiological oestrus in the mare by vaccination against GnRH. Australian Veterinary Journal 85, 39-45. doi: 10.1111/j.1751-0813.2006.00092.x

Etter, D. R., Van Deelen, T. R., Ludwig, D. R., Kobal, S. N., and Warner, R. E. (2000). Management of white-tailed deer in Chicago, Illinois, forest preserves. In 'Proceedings of the 19th Vertebrate Pest Conference'. (Eds T. P. Salmon and A. C. Crabb.) pp. 190-196. (University of California: Davis, CA.)

Fagerstone, K. A., Coffey, M. A., Curtis, P. D., Dolbeer, R. A., Killian, G. J., Miller, L. A., and Wilmot, L. M. (2002). Wildlife fertility control. Technical Review 02-2. The Wildlife Society, Bethesda, MD.

Flowerdew, J. R., and Ellwood, S. A. (2001). Impacts of woodland deer on small mammal ecology. Forestry 74, 277-287. doi: 10.1093/forestry/ 74.3.277

Fuller, R. J., and Gill, R. M. A. (2001). Ecological impacts of increasing numbers of deer in British woodland. Forestry 74, 193-199. doi: 10.1093/ forestry/74.3.193

Gortázar, C., Acevedo, P., Ruiz-Fons, F., and Vicente, J. (2006). Disease risks and overabundance of game species. European Journal of Wildlife Research 52, 81-87. doi: 10.1007/s10344-005-0022-2

Harder, J. D., and Kirkpatrick, R. L. (1994). Physiological methods in wildlife research. In 'Research and Management Techniques for Wildlife and Habitats', 5th edn. (Ed. T. A. Bookhout.) pp. 275-306. (The Wildlife Society: Bethesda, MD.)

Harder, J. D., and Moorhead, D. L. (1980). Development of corpora lutea and plasma progesterone levels associated with the onset of the breeding season in white-tailed deer (Odocoileus virginianus). Biology of Reproduction 22, 185-191. doi: 10.1095/biolreprod22.2.185

Hobbs, N. T., Bowden, D. C., and Baker, D. L. (2000). Effects of fertility control on populations of ungulates: general, stage-structured models. Journal of Wildlife Management 64, 473-491. doi: 10.2307/3803245

Horsley, S. B., Stout, S. L., and deCalesta, D. S. (2003). White-tailed deer impact on the vegetation dynamics of a northern hardwood forest. Ecological Applications 13, 98-118. doi: 10.1890/1051-0761(2003) 013[0098:WTDIOT]2.0.CO;2

Hurlbert, S. H. (1984). Pseudoreplication and the design of ecological field experiments. Ecological Monographs 54, 187-211. doi: 10.2307/ 1942661

Killian, G. J., Diehl, N. K., Miller, L. A., Rhyan, J. C., and Thain, D. (2006a). Long-term efficacy of three contraceptive approaches for population control of wild horses. In 'Proceedings of the 22nd Vertebrate Pest Conference'. (Eds R. M. Timm and J. M. O'Brien.) pp. 67-71. (University of California: Davis, CA.)

Killian, G. J., Eisemann, J. D., Wagner, D., Werner, J., Shaw, D., Engeman, R., and Miller, L. A. (2006b). Safety and toxicity evaluation of GonaCon immunocontraceptive vaccine in white-tailed deer. In 'Proceedings of the 22nd Vertebrate Pest Conference'. (Eds R. M. Timm and J. M. O'Brien.) pp. 82-87. (University of California: Davis, CA.)

Killian, G. J., Miller, L. A., Rhyan, J. C., and Doten, H. (2006c). Immunocontraception of Florida feral swine with a single-dose GnRH vaccine. American Journal of Reproductive Immunology 55, 378-384. doi: 10.1111/j.1600-0897.2006.00379.x

Kuser, J., and Applegate, J. E. (1985). Princeton Township: the history of a nodischarge ordinance's effect on deer and people. In 'Transactions of the 42nd Northeast Fish and Wildlife Conference'. (Ed. M. Sayre.) pp. 150-155. (University of Massachusetts: Amherst, MA.)

Levy, J. K., Miller, L. A., Crawford, P. C., Ritchey, J. W., Ross, M. K., and Fagerstone, K. A. (2004). GnRH immunocontraception of male cats. Theriogenology 62, 1116-1130. doi: 10.1016/j.theriogenology.2003. 12.025

Lunney, D., Eby, P., Hutchings, P., and Burgin, S. (Eds) (2007). 'Pest or Guest: The Zoology of Overabundance.' (Royal Zoological Society of New South Wales: Sydney.) 
Martin, R. W. (1985). Overbrowsing, and decline of a population of the koala, Phascolarctos cinereus, in Victoria. I. Food preference and food tree defoliation. Australian Wildlife Research 12, 355-365. doi: 10.1071/ WR9850355

McShea, W. J., and Rappole, J. H. (2000). Managing the abundance and diversity of breeding bird populations through manipulation of deer populations. Conservation Biology 14, 1161-1170. doi: 10.1046/j.15231739.2000.99210.x

McShea, W.J., Monfort, S. L., Hakim, S., Kirkpatrick, J., Liu, I., Turner, J. W.Jr, Chassy, L., and Munson, L. (1997a). The effect of immunocontraception on the behavior and reproduction of white-tailed deer. Journal of WildlifesManagement 61,560-569. doi: 10.2307/3802615

McShea, W. J., Underwood, H. B., and Rappole, J. H. (Eds.) (1997b). 'The Science of Overabundance: Deer Ecology and Population Management.' (Smithsonian Institution Press: Washington, D.C.)

Merrill, J. A., Cooch, E. G., and Curtis, P. D. (2003). Time to reduction: factors influencing management efficacy in sterilizing overabundant white-tailed deer. Journal of Wildlife Management 67, 267-279. doi: 10.2307/ 3802768

Miller, L. A., Johns, B. E., Elias, D. J., and Crane, K. A. (1997). Comparative efficacy of two immunocontraceptive vaccines. Vaccine 15, 1858-1862. doi: 10.1016/S0264-410X(97)00141-2

Miller, L. A., Johns, B. E., and Killian, G. J. (2000). Immunocontraception of white-tailed deer with GnRH vaccine. American Journal of Reproductive Immunology 44, 266-274. doi: 10.1111/j.8755-8920.2000. 440503.x

Miller, L. A., Rhyan, J. C., and Killian, G. J. (2003). Evaluation of GnRH contraceptive vaccine using domestic swine as a model for feral hogs. In 'Proceedings of the 10th Wildlife Damage Management Conference'. (Eds K. A. Fagerstone and G. W. Witmer.) pp. 120-127. (National Wildlife Research Center: Fort Collins, CO.)

Miller, L. A., Rhyan, J. C., and Drew, M. (2004a). Contraception of bison by GnRH vaccine: a possible means of decreasing transmission of brucellosis in bison. Journal of Wildlife Diseases 40, 725-730

Miller, L. A., Rhyan, J. C., and Killian, G. J. (2004b). GonaCon ${ }^{\mathrm{TM}}$, a versatile GnRH contraceptive for a large variety of pest animal problems. In 'Proceedings of the 21st Vertebrate Pest Conference'. (Eds R. M. Timm and W. P. Gorenzel.) pp. 269-273. (University of California: Davis, CA.)

Miller, L. A., Gionfriddo, J. P., Fagerstone, K. A., Rhyan, J. C., and Killian, G. J. (2008). The single-shot GnRH Immunocontraceptive Vaccine $\left(\mathrm{GonaCon}^{\mathrm{TM}}\right)$ in white-tailed deer: comparison of several GnRH preparations. American Journal of Reproductive Immunology 60, 214-223. doi: 10.1111/j.1600-0897.2008.00616.x

Muller, L. I., Warren, R. J., and Evans, D. L. (1997). Theory and practice of immunocontraception in wild animals. Wildlife Society Bulletin 25, 504-514.

Nash, P. B., James, D. K., Hui, L. T., and Miller, L. A. (2004). Fertility control of California ground squirrels using GnRH immunocontraception. In 'Proceedings of the 21 st Vertebrate Pest Conference'. (Eds R. M. Timm and W. P. Gorenzel.) pp. 274-278. (University of California: Davis, CA.)

Palmer, S. C. F., Mitchell, R. J., Truscott, A.-M., and Welch, D. (2004) Regeneration failure in Atlantic oakwoods: the roles of ungulate grazing and invertebrates. Forest Ecology and Management 192, 251-265. doi: 10.1016/j.foreco.2004.01.038

Patton, M. L., Jöchle, W., and Penfold, L. M. (2007). Review of contraception in ungulate species. Zoo Biology 26, 311-326. doi: 10.1002/zoo.20154
Perry, K. R., Miller, L. A., and Taylor, J. (2008). M. avium bacterium: is it an essential ingredient for a single-injection GnRH immunocontraceptive vaccine. In 'Proceedings of the 23rd Vertebrate Pest Conference'. (Ed. R. M. Timm.) pp. 253-256. (University of California: Davis, CA.)

Plotka, E. D., Seal, U. S., Scholler, G. C., Karns, P. D., and Keenlyne, K. D. (1977). Reproductive steroids in the white-tailed deer (Odocoileus virginianus borealis). I. Seasonal changes in the female. Biology of Reproduction 16, 340-343. doi: 10.1095/biolreprod16.3.340

Plotka, E. D., Seal, U. S., Verme, L. J., and Ozoga, J. J. (1980). Reproductive steroids in deer. III. Luteinizing hormone, estradiol and progesterone around estrus. Biology of Reproduction 22, 576-581.

Pojar, T. M., and Bowden, D. C. (2004). Neonatal mule deer fawn survival in west-central Colorado. Journal of Wildlife Management 68, 550-560. doi: 10.2193/0022-541X(2004)068[0550:NMDFSI]2.0.CO;2

Purswell, B. J., and Kolster, K. A. (2006). Immunocontraception in companion animals. Theriogenology 66, 510-513. doi: 10.1016/ j.theriogenology.2006.04.018

Rhodes, O. E. Jr, Novak, J. M., Smith, M. H., and Johns, P. E. (1986). Assessment of fawn breeding in a South Carolina deer herd. Proceedings of the Annual Conference of the Southeastern Association of Fish and Wildlife Agencies 40, 430-437.

Rooney, T. P., and Waller, D. M. (2003). Direct and indirect effects of whitetailed deer in forest ecosystems. Forest Ecology and Management 181, 165-176. doi: 10.1016/S0378-1127(03)00130-0

Rudolph, B. A., Porter, W. F., and Underwood, H. B. (2000). Evaluating immunocontraception for managing suburban white-tailed deer in Irondequoit, New York. Journal of Wildlife Management 64, 463-473. doi: $10.2307 / 3803244$

Rutberg, A. T., Naugle, R. E., Thiele, L. A., and Liu, I. K. M. (2004). Effects of immunocontraception on a suburban population of white-tailed deer Odocoileus virginianus. Biological Conservation 116, 243-250. doi: 10.1016/S0006-3207(03)00195-2

Schneider, B. A. (1982). 'Pesticide Assessment Guidelines Subdivision G: Product Performance.' US Environmental Protection Agency Document Number EPA 540/9-82-026. (US EPA Office of Pesticides and Toxic Substances: Washington, D.C.)

St John, B. (1997). Risk assessment and koala management in South Australia. Australian Biologist 10, 47-56.

Stills, H. F. Jr, and Bailey, M. Q. (1991). The use of Freund's complete adjuvant. Lab Animal 20, 25-30.

Stout, R. J., Knuth, B. A., and Curtis, P. D. (1997). Preferences of suburban landowners for deer management techniques: a step towards better communication. Wildlife Society Bulletin 25, 348-359.

Whitten, K. R. (1995). Antler loss and udder distention in relation to parturition in caribou. Journal of Wildlife Management 59, 273-277. doi: $10.2307 / 3808940$

Zeng, X. Y., Turkstra, J. A., Tsigos, A., Meloen, R. H., Liu, X. Y., Chen, F. Q., Schaaper, W. M. M., Oonk, H. B., Guo, D. Z., and van de Wiel, D. F. M. (2002). Effects of active immunization against GnRH on serum LH, inhibin A, sexual development and growth rate in Chinese female pigs. Theriogenology 58, 1315-1326. doi: 10.1016/S0093-691X(02)01036-1

Manuscript received 18 April 2008, accepted 5 January 2009 